\title{
Actin-Related Protein 3B
}

National Cancer Institute

\section{Source}

National Cancer Institute. Actin-Related Protein 3B. NCI Thesaurus. Code C152042.

Actin-related protein 3B (418 aa, $\sim 48 \mathrm{kDa}$ ) is encoded by the human ACT R3B gene. This protein plays a role in actin binding and organization of the cytoskeleton. 